\title{
1. General reflections on current threats and challenges to, and opportunities for, the exercise of economic rights by EU citizens
}

\section{Sybe de Vries}

\section{INTRODUCTION}

Economic rights based on the fundamental Treaty freedoms (Treaty on the Functioning of the European Union - TFEU), which include the free movement of goods, persons, services and capital, have always belonged to the core European Union (EU) citizenship rights. That explains why they are considered a separate category of citizenship rights, as is also recognized by the EU Charter of Fundamental Rights. Using the classic typology of T.H. Marshall (1950) distinguishing between civil, political and social rights, the EU Charter now adds the category of economic rights, which for Marshall were included in the civil rights.

Due to legal developments, economic rights, particularly through the Treaty freedoms, have been placed at the heart of the EU legal order, constituting the legal framework for the creation of a Single Market and the development of all kinds of related, horizontal and flanking policies (De Vries 2006). But despite the significance of the Single Market, there continue to be barriers to citizens exercising their rights. These barriers range from legal barriers to more practical and linguistic barriers, many of which are addressed in this book.

This chapter focuses on two challenges and possible threats to the exercise of EU citizens' economic rights. The first challenge relates to the question of how the EU Single Market must be defined and envisaged, particularly in relation to the social market economy, which is a key task according to Article 3 TEU. In the discussions on Brexit in the United Kingdom (UK) much emphasis has been put on the benefits of free trade for the UK. The internal market seems to be pictured here as a narrowly defined, neo-liberal, market-based and purely economic project. 
The question is whether this image of the internal market is in fact not misleading. True, the social dimension of the internal market remains underdeveloped, at least compared to the national level, where economic rights are more socially embedded. In the face of growing inequality in Europe and contestation of the European integration process, an immature 'social market' at EU level seems increasingly problematic, also for the exercise of citizens' economic rights. Citizens may call upon their government to protect the domestic (labour) market, which may lead to restrictions on free movement and a backlash of (socio-)economic rights. Making Europe's economy more inclusive is also an important aim, mentioned in the Commission's White Paper on the Future of Europe (European Commission 2017). The question, though, remains of how this should be realized in practice.

A second set of (related) challenges concerns the potential impact of a number of developments, including Brexit, on the presumed unity of the internal market. The Commission's White Paper on the Future of Europe includes 'differentiated integration' as one of the scenarios for the future development of the European Union. In his call for deeper integration in a number of policy fields such as the Economic and Monetary Union, French President Macron also sees differentiated integration as a viable option. The question is what this might entail for the internal market. Would it for instance be imaginable that more variation exists between Member States with respect to their commitment to the four freedoms? What does that mean for the economic rights of citizens? After a short introduction to the identification and regulation of national and EU economic rights and their legal status, these two challenges are addressed in the following sections.

\section{THE IDENTIFICATION AND REGULATION OF ECONOMIC RIGHTS WITHIN THE EU}

\section{Economic Rights at National Level}

At the national level economic rights of citizens have been identified as rights pertaining to market activities and rights that are concerned with the regulation of factors of production (capital and labour) and business activities. Property, labour and economic enterprise are the three main areas in which economic rights can be recognized. But their legal recognition and constitutional status depend on the economic order of the Member State and, related to this, to their historical development. EU Member States share a common history in the development of economic rights, but there 
are also differences, which relate to different legal traditions and political developments. For example, the industrial revolution has had an impact on how in the UK traditional legal concepts have been modified or adapted, and property and private initiative have been regulated. In other countries the focus was laid upon the adoption of legislation, which aimed at adapting the legal system to the needs of an industrial and post-industrial economy (De Vries et al. 2015).

During the industrial revolution the prevailing liberal viewpoint informed the codification of civil law, providing the instruments for a more flexible and predictable use of production factors and thus for more legal certainty. The growing complexity of the economies of the Member States increasingly required governmental intervention and the adoption of public economic law regulations. More recently, however, there has been a trend in all Member States to diminish the role of the government in regulating economic rights through a process of liberalization, privatization and deregulation. Yet, at the same time, there are strong calls for protecting public services within the EU, and in some Member States for reversing privatization and liberalization.

In addition, at both EU and national levels, laws have been adopted to monitor competition and to prevent the emergence of monopolies in previously heavily regulated sectors of the economy, for example in the telecommunications, postal services and energy sectors. At the same time, it was recognized that, for the sake of fair competition and consumer protection, free economic initiative must be limited, which resulted in the regulation of specific sectors of the economy at the EU level, such as the financial market and the markets in the field of public services.

As stated above, alongside (different) legal traditions, political differences have also been important in identifying and defining economic rights and liberties. The desire to protect citizens, who are within the production process (as workers and consumers), has led to the development of the welfare state, guaranteeing basic social rights to its citizens. Although this has been a common phenomenon for all Member States, they differ in the way in which the legal systems have accommodated social concerns and have balanced economic and social rights, depending inter alia on the political system in the respective Member State. ${ }^{1}$ Contrary to their EU counterpart, national economic rights within the Member States thus seem to be less 'stable'. In determining which rights are considered as economic rights in the various Member States, the boundaries between economic and social rights need to be taken into account, which differ in every State (De Vries et al. 2015). 


\section{Fundamental Position of Economic Rights at EU Level}

The economic rights of EU citizens are first and foremost reflected in the four economic freedoms on goods, services, persons and capital, which seek to abolish both discriminatory and non-discriminatory barriers to trade and free movement and have thus been pivotal for the market integration process. In addition, economic rights have since the Treaty of Lisbon been included in the EU Charter of Fundamental Rights, which may have reinforced their particularly strong position (see below).

As the economic rights of EU citizens are 'old rights', the ways in which these rights should be understood and have been developed, particularly in the case law of the Court of Justice of the European Union (CJEU), are well documented in (legal) literature (see, for example, with regard to goods: Oliver 2004; services and persons: O'Leary 2011; the four freedoms in general: Barnard 2016). It appears from the outset that economic rights of EU citizens based on the four freedoms entail a right to equal treatment, that is, the right not to be discriminated against and the right to freedom of movement (O'Leary 2011). But the CJEU went even further by prohibiting all kinds of restrictions - that is, national rules - which restrict market access, thereby offering citizens a right to gain access to the market in another Member State (Snell 2010). The idea of market access is based on the principle that goods (or services) lawfully produced and marketed in one Member State 'should presumptively have free and unrestricted access to the market in another Member State' (Barnard 2016). ${ }^{2}$

This substantive right of citizens to be treated equally on the EU Single Market and to gain access to markets of other Member States was the result of a gradual process of 'juridification' of the European marketbuilding project, starting with the principal Van Gend \& Loos and Costa v. Enel decisions of the CJEU. ${ }^{3}$ Through these decisions the seemingly political-technical commitments of Member States in the EEC Treaty (the predecessor of the TFEU) were transformed into (economic) principles and accompanying substantive rights. In the seminal Van Gend \& Loos case the Court held that 'the Community constitutes a new legal order of international law for the benefit of which the states have limited their sovereign rights, albeit within limited fields, and the subjects of which comprise not only Member States but also their nationals'. This 'new legal order' allowed the CJEU to postulate the principle of direct effect, introducing substantive rights for individuals and, in the Costa $v$. Enel case, the principle of the primacy of Community law over national law.

Herewith the Court created a law-based order in which the economic freedoms that lay at the heart of this new legal order acquired a 
fundamental status and played a vital role in building Europe's economic constitution. The CJEU itself has repeatedly enhanced their fundamental status in its case law; a status that has been reinforced by the EU Charter of Fundamental Rights, which includes economic rights such as the freedom to choose an occupation or profession (Article 15), the freedom to conduct a business (Article 16) and the right to property (Article 17). In a number of cases, the Court made clear that the economic Treaty freedoms could also be seen as a specific amplification of the Charter. ${ }^{4}$

The fact that, in establishing the internal market, the focus has been laid on trade liberalization, free movement and the elimination of barriers set up by national governments - the normative, functional method of integration (Mortelmans 1985) - has extended the scope of application of EU internal market law and EU economic rights enormously. Hardly any area of socio-economic life escapes the EU internal market (Weatherill 2013). After all, what is crucial is that national measures have an effect on free movement. The specific public interest character of an activity, or ethical considerations, do not play a role in determining whether the four economic freedoms are applicable in the first place. And it is also irrelevant whether the Member State is primarily competent to regulate certain matters, as in the field of taxation, healthcare or social policies.

\section{CHALLENGE I: THE INCLUSIVE SINGLE MARKET}

But there are possibilities for Member States to justify measures that restrict trade and free movement for public interest reasons. And in adopting harmonization measures - that is, secondary legislation in the form of directives or regulations - the EU legislator also has within the context of its powers in the field of the internal market the obligation to protect noneconomic interests (see hereafter). The EU Single Market is thus not per se biased by a neo-liberal conception of the market. Hence it should be borne in mind that 'the realization of an internal market and the liberalization of trade are not ends in themselves, but important tools to increase welfare and promote sustainable development' (Chalmers 1995).

More difficult to assess on the basis of the Treaty provisions is what type of internal market the drafters of the Treaties had in mind. Article 26 TFEU merely includes a definition of the internal market but does not say how the internal market should be shaped, how it relates to national autonomy and how deregulatory it may be, what the relationship is between the internal market and the social market economy, or what the role of citizens is more generally in the internal market. 


\section{Integrating Non-Economic Interests and Fundamental Rights of EU Citizens into EU Internal Market Law}

\section{The role of the Court of Justice in softening the internal market freedoms}

Due to the rather unclear and ambiguous Treaty provisions, it has been particularly the task of the CJEU to further clarify the reach and limits of internal market law. Economic rights of citizens are not absolute, neither at national nor at EU level. As Oliver put forward, 'Article 34 TFEU [on the free movement of goods] does not provide for a general freedom to trade or the right to the unhindered pursuit of one's commercial activities, but is aimed at restrictions on imports'. And, 'Article 34 must on no account be confused with article 16 of the Charter of Fundamental Rights', which lays down the freedom to conduct a business. Oliver made this observation in relation to the Court's judgment in the Keck case, in which the Court narrowed down the substantive reach of Article 34 TFEU into national regulatory autonomy by excluding national rules, which regulate certain selling arrangements, from its scope of application provided that these rules are non-discriminatory (Oliver 2011, pp. 1447-1448). ${ }^{5}$ Selling arrangements or market circumstances rules concern who sells the product (pharmacist) and when (Sundays, at night). According to the CJEU such rules are not such as to hinder directly or indirectly, actually or potentially, trade between Member States (Mortelmans 1991).

Moreover, the EU Treaty framework underlines the relative importance of the four freedoms in the Treaty. ${ }^{6}$ Where EU economic rights of citizens clash with other citizens' rights, which are defended by Member States, and citizens invoke their right to trade and free movement before a court, these conflicting rights will need to be balanced.

The Treaty and the Court's case law offer various possibilities for the protection of non-economic interests and other fundamental (social) rights of citizens within the context of the internal market. Specific derogations from the four freedoms are included in the Treaty allowing the Member State to uphold measures that seek to protect public policy, public health or other specific interests. In addition the CJEU has accepted that overriding reasons of general interest (or mandatory requirements), which are not explicitly mentioned by the Treaty, may also justify restrictions on free movement. Furthermore, the binding EU Charter of Fundamental Rights reinforces the importance of fundamental rights at EU level, which include civil, political, economic and social rights. The Charter entails an equal ranking of fundamental rights and fundamental freedoms, ${ }^{7}$ as is confirmed by Article 52 of the EU Charter, which requires a balancing of conflicting fundamental rights according to the principle of proportionality. 
In its case law, the CJEU developed a 'scheme' under which EU economic rights can be limited with a crucial role for the principle of proportionality (Weatherill 2015). In a rather extensive and dynamic body of case law we see how the CJEU has taken into account public interests, typically national values, ethical issues or politically sensitive questions, such as the protection of weaker consumers, a regional language or the regulation of games of chance. ${ }^{8}$ Hence we can see that the Court adopts a balancing approach wherein, in principle, sufficient weight is given to national values and other citizenship rights. This also goes true for other fundamental rights, which are also enshrined in the EU Charter of Fundamental Rights, such as the freedom of speech, the freedom of assembly, ${ }^{9}$ human dignity, ${ }^{10}$ and the rights to strike and take collective action. ${ }^{11}$

The approach of the Court thus provides for a correction mechanism preventing economic rights becoming too dominant vis-à-vis other citizenship rights; however, in some cases the Court has been accused of too easily subsuming other fundamental rights under EU economic rights of citizens, which is discussed below.

\section{The role of the EU legislator in softening the internal market freedoms}

As Member States still have recourse to exceptions, it is crucial for the sustainability of the internal market that the EU can establish common rules. In using Article 114 TFEU - the main legal basis for harmonization measures in the field of the internal market - the EU legislator acts as 'respondent to the pre-existing diverse regulatory choices among the Member States' (Weatherill 2015, p. 228). Harmonization of national laws therefore has a dual purpose: it creates a level playing field by setting common standards for the internal market, and it provides for (reregulatory) protection of non-economic standards, which were previously regulated by Member States. Hence, the very nature of harmonization requires that the EU legislator accommodates non-economic interests and other fundamental citizenship rights in internal market legislation. This dual nature is further emphasized by Article 114(3) TFEU, explicitly calling upon the European Commission to base its proposals upon a high level of environmental and consumer protection, and health and safety protection.

In addition the Treaty includes various integration or horizontal clauses', which require the EU legislator to take on board non-economic interests in harmonization measures. A well-known example is the environmental integration clause of Article 11 TFEU, demanding that environmental protection requirements must be integrated into the definition and implementation of other policies. In a similar vein the Treaty contains an integration clause referring to social protection (see below). 
Lastly, the EU Charter confirms the view that EU internal market law is concerned with the protection of other, citizenship interests, and that it will have to comply with these interests and fundamental rights. According to Article 52 of the EU Charter, conflicting fundamental rights of EU citizens need to be balanced. In cases on privacy and data protection the CJEU made clear that the margin of discretion for the EU legislator in the field of fundamental rights is considerably reduced. ${ }^{12}$

\section{Difficulties in Creating a More Socially Inclusive Internal Market}

Despite the above-mentioned, there continue to be difficulties in embedding economic rights with social rights and values within the current internal market context. These difficulties have become particularly noticeable within the context of the Economic and Monetary Union, where EU institutions appear to be quite powerless to protect social rights of citizens and combat social inequality and injustice in those Member States that suffered most from the economic and financial crisis (see also Hatzopoulos, Chapter 6 in this book; Barnard 2015).

\section{Strong connection between economic and social rights of citizens}

Economic and social rights may conflict with each other but also have reinforcing economic effects, where income and redistributive policies enhance consumption. Social policies, though, burden the market with costs and rigidities, whereas free competition produces social injustices and social inequalities that damage the civic and social rights of workers, the self-employed and even entrepreneurs or competitors (Veldman and De Vries 2015, p. 71). To prevent social unrest and instability - and thus a backlash of economic rights as well - markets must be interwoven into the fabrics of society (Veldman and De Vries 2015; Polyani 1994). At the national level social rights are taken into account in defining the boundaries of economic rights, and the welfare state addresses negative externalities of market mechanisms. But this system is put under pressure by the European integration process. The possibility in the EU to sell goods and services cross-border, which are produced and marketed under the pay and working conditions that apply in the home Member States with limited legislative powers for the EU in the social policy field - has fuelled social competition (Verschueren 2015, p. 150). The questions are, first, whether the limited extent to which social values and social rights have been explicitly interwoven into the EU's fabric is problematic and may threaten the stability not only of national markets but also of the EU internal market; and second, whether the Treaty's current rhetoric on the social market economy, equality, social progress and full employment 
would be capable of strengthening the social face of the EU and building a more inclusive and fairer Union. In a similar vein, how important in this respect are the inclusion of fundamental social rights in the EU Charter of Fundamental Rights and policy documents such as, in particular, the Commission's paper on the European Pillar of Social Rights?

\section{The potential of the internal market to reinforce social rights}

The creation of a more social Europe was originally not seen as an aim in itself, but as strongly linked to the establishment of the common market. And the harmonization of levels of social protection and social regulation amongst the six founding Member States was not considered as a precondition for the integration of national markets into a Community-wide internal market (Veldman and De Vries 2015, p. 72). Rather, the establishment of a common market with expected productivity gains in each Member State would have improved the living and working conditions of European citizens. A number of documents of the European Commission and the Council underlined the importance of the social dimension of the internal market, such as the Spaak report, which laid ground for the establishment of the common market and the European Economic Community. But a uniform level of social protection across the Community was not foreseen and would not be regarded as desirable (De Schutter 2006, p. 119).

The EEC Treaty also included references to social values, such as the improvement of living and working conditions, the principle of equal pay for male and female workers (Article 119 EEC), as well as a provision on closer cooperation in the social policy field (Article 118 EEC). The idea of a pan-European social market economy, to which the EU has committed itself more forcefully since the Treaty of Lisbon through its explicit reference in Article 3(3) TEU, thus appears to have been present ever since the inception of the European Economic Community. This coupling of social objectives to the internal market and their recognition as part and parcel of economic integration was confirmed by the CJEU in the Defrenne case, wherein it held that Article 119 EEC (now Article 157 TFEU) on equal pay for men and women, 'forms part of the social objectives of the Community, which is not merely an economic union, but is at the same time intended ... to ensure social progress and the constant improvement of the living and working conditions of their peoples' ${ }^{13}$ Although this provision was included in the Treaty to combat distortions of competition as a result of States being given an unfair competitive advantage in industries employing a large proportion of women, it can also serve as an example of how economic rights of citizens may contribute to the protection of social rights.

Meanwhile, the dual nature of harmonization within the context of the internal market allowed the Community legislator to adopt binding 
standards on the protection of workers and social welfare. Various directives were adopted on the basis of Article 100 EEC (now Article 115 TFEU), like the Directive on the safeguarding of employees' rights in the event of transfers of undertakings or the Directive on the protection of employees in case of insolvency of their employer. ${ }^{14}$ According to Weatherill, the measures demonstrate that 'there has been at times in the development of the EU a political readiness to treat the harmonization of standards of social protection as a required element within the building of the internal market' (Weatherill 2017, p.28). But the regulation of social rights and values remained eclectic and fragmented, and was seen as primarily necessary for a fair competition on the internal market.

\section{The legal and political limits to further strengthen the social dimension of the internal market}

Despite the 'social traits' of the internal market and despite the current Treaties, including the social market economy, and the binding EU Charter of Fundamental Rights, the development of a substantive social policy at EU level meets with political resistance and legal constraints. At the same time the Treaty framework and structure plead - and have always pleaded - against an aggressive decentralized, deregulated internal market model, as both Weatherill (2017) and Oliver (2011) claim.

But the competences granted to the EU to enact legislative, binding measures in the social policy field are limited. The internal market legal basis of Article 114 TFEU explicitly excludes the possibility to adopt harmonization measures in relation to the rights and interests of employed persons. Furthermore, the EU has limited powers to pursue a social policy on the basis of Article 157 TFEU, although it does allow the EU to adopt minimum harmonization measures (Directives) for the protection of workers. Other legal bases that are linked to the internal market require unanimity, such as Article 115 TFEU or Article 352 TFEU for unforeseen cases. In addition, the EU Charter is of little help here as it explicitly states in Article 51(1) that it does not establish any new power or task for the EU, nor modify powers and tasks as defined in the Treaties.

So far there appears to have been a lack of political will to further pursue EU-wide social policies, although the adoption of the European Pillar of Social Rights indicates that might well be changing. The challenge, however, is how to transform the aspirations as set out in the Pillar into concrete, legally binding EU measures, which are not in the first place dictated by an economic rationale but by social values and human dignity (http://eulaw analysis.blogspot.nl/2017/03/from-austerity-back-to-legitimacy.html).

The current proposal for a revised posting of workers Directive, which aims to restore the balance between the free movement of services and 
workers' protection and thereby to create a fairer, internal labour market, constitutes a good illustration of this. The Directive is an example of internal market legislation, based upon Articles 53(1) and 62 TFEU, whereas the proposal also refers to Articles 151 and 153 TFEU on social policy. ${ }^{15}$

The limited legislative activity of the EU leaves the CJEU the pivotal card to decide on clashes between EU economic rights and (nationally) protected social rights, which may lead to suboptimal solutions (Veldman and De Vries 2015). The reasons for this are various. The scope of application of the EU Charter is limited in general, and particularly with respect to social rights and principles, which are often framed as 'principles' that are not judicially cognizable and need further elaboration in legislation before they can be relied upon in court. ${ }^{16}$ Judgments such as Viking and Laval on the right to take collective action have been heavily criticized for too easily subordinating fundamental social rights to economic rights and thereby upsetting the principle of equal ranking for fundamental rights and fundamental freedoms. Although these rulings can be seen as 'aberrant' and 'out of line with the orthodoxy' of EU free movement law (Weatherill 2015), they do raise concerns about how to establish at EU level an equilibrium between conflicting market-making and marketcorrecting policies, with social values becoming too easily subsumed under economic values.

The limited jurisdiction of the CJEU in interpreting EU internal market legislation under the preliminary ruling procedure may entail that the Court does not take into account fundamental (social) rights for a variety of reasons (De Vries 2015). In the Alemo Herron case, for instance, the Court in interpreting the Directive on employees' rights in the event of transfer for undertakings, even relied on Article 16 EU Charter on the freedom to conduct a business to emphasize the importance of employers' economic rights under the Directive. The specific aims of this internal market legislation are, however, the protection of the rights of employees, of workers, which rights are also included in Article 30 of the EU Charter. But this provision did not - and could not - serve as a counterweight to the rights of private firms under the Directive and Article 16 of the EU Charter. $^{17}$

\section{A way forward}

So how could economic rights be more socially embedded in the EU legal framework? A structural and drastic solution is to change the Treaty and include substantive powers in the social policy field. It is doubtful whether this is feasible in the nearby future. A scenario could be that a number of Member States decide to strengthen cooperation in the social policy field. But considering the extent to which economic and social rights are 
intertwined, the question is how divergent these policies should be, also with a view to preventing distortions of competition and new barriers to the exercise of economic rights of EU citizens. Differentiated integration in the social policy field, however, is not new as, for instance, Protocol No. 30 on the application of the Charter to Poland and the UK declares inter alia that the social rights under Title IV (Solidarity) do not create justiciable rights applicable in Poland or in the UK (Barnard and Peers 2017, p. 251).

Another possibility is offered by the EU's existing and broad powers in the field of the internal market. Re-regulation of social values and social rights within the internal market, considering the dual nature of harmonization, is certainly not impossible. Furthermore, Article 9 TFEU requires the EU in defining and exercising its policies to safeguard an adequate level of social protection. Of course, the existence of political will is crucial. The positive outcome of the debate within the European Parliament and the Council on the revision of the posting of workers Directive shows that may not be merely illusory any more. ${ }^{18}$

Once obvious references to social rights and principles have been included in secondary EU legislation, it will be easier for the Court to take these into account when faced with difficult questions of interpretation. Hence the CJEU should not, contrary to its approach in Alemo Herron, 'use' the EU Charter to upset the balancing exercise, which is carried out by the legislator (Barnard 2015, p. 183).

Furthermore, more account should be taken of the structural differences that exist between national social systems at the level of policy-making and in the case law of the Court. The EU Charter and the social rhetoric in the Treaty should be reflected more in the Court's case law. The social rights and principles enshrined in the Charter of Fundamental Rights may constitute a counterweight to economic rights. Here, there is reason for optimism, considering the inclusive narrative of free movement case law and the analytical scheme that is usually applied to EU free movement law (Weatherill 2015).

Finally, in order to further socially embed economic rights, one could also think of promoting the collective dimension of these rights and horizontal subsidiarity. Rather than continuing to focus on individual economic rights of its citizens, on liberalization, privatization and free competition, the European Union could also choose to more actively protect and pursue public services, general interests or common goods. 


\section{CHALLENGE II: PRESERVING COHERENCE IN THE FACE OF LURKING DISINTEGRATION}

Differentiated integration is not a new phenomenon, but had already found its way into the fabric of the European Union, of which Schengen for the field of the free movement of persons and the Economic and Monetary Union are perhaps the most noticeable examples. In addition, the possibility for Member States to go further, to proceed with measures - which could otherwise not be adopted - via the route of 'enhanced cooperation', is also an illustration of differentiated integration. These alternatives are generally regarded as the result of increasing heterogeneity of economic, social and political conditions of Member States (Barnard and Peers 2017, p. 136). Opt-out arrangements for Member States fit into this development as well.

Against this increasingly heterogeneous background, the unity of the internal market - and, strongly related to this, the unity of EU law - seems to stand out. Fragmentation must be prevented, since it would undermine the EU legal order and the unity of the internal market (Prechal 2006, p. 14). Enhanced cooperation, for instance, must thus meet stringent legal requirements, including the requirement that it must not undermine the internal market (Barnard and Peers 2017). In response to the idea that the UK should remain in the internal market, but only in respect of the free movement of goods and services, the European Commission repeatedly stated that the EU Single Market and its four freedoms are indivisible. In the words of Donald Tusk, the President of the European Council, there are no cakes on the table but there will be salt and vinegar instead. Being part of the Single Market means that one also has to accept the free movement of persons. But is the internal market indeed characterized by a large degree of unity, or for that matter homogeneity, and are the four freedoms indivisible?

\section{Coherence Between the Four Freedoms}

Let us first look at a number of legal and societal developments which support the idea of a unified or homogeneous internal market. According to Article 26 TFEU the internal market shall comprise an area in which the free movement of goods, persons, services and capital is ensured. For all freedoms, the key principles of free movement and non-discrimination have been further elaborated and explained in the case law of the CJEU and in EU legislation. The free movement of economically active persons, including workers, has always been considered crucial for the establishment and functioning of the internal market ever since the inception of the EEC. 
However, a common labour market was not (explicitly) foreseen in the Treaty (Lewin 1965, p. 300).

Looking at the case law of the CJEU there is a considerable degree of coherence in the way in which the free movement rules are interpreted (Shuibhne 2013; De Vries 2006, p. 332). This process of coherence has carried on through essentially three stages. Firstly, the four freedoms have a broad material and personal scope of application. Due to a broad interpretation of the concept of economic activity by the CJEU, which may include the provision of healthcare, gambling services, collective actions by trade unions or the provision of abortion, hardly any area of socio-economic policies escapes the applicability of the four freedoms (Weatherill 2017, p. 5). Furthermore, even acts by non-state actors that are discriminatory or restrict free movement may, under certain conditions, be directly challenged on the basis of the free movement rules before a national court, which is referred to as horizontal direct effect. However, this possibility has not been accepted for the free movement of goods, at least not explicitly. ${ }^{19}$

Secondly, the four freedoms prohibit both discriminatory and nondiscriminatory restrictions on trade and free movement. The market access-based test has emerged as a key test for all freedoms, whereby the CJEU has gone beyond granting EU citizens a mere right to equal treatment by also prohibiting national restrictive measures which prevent citizens from obtaining market access in another Member State (Barnard 2016). This has been an important step towards removing barriers to the creation of a (true) Single Market where persons and services can, in principle, move freely.

Thirdly and lastly, the Court has developed for all four freedoms a 'rule of reason' for mandatory requirements, which are in the public interest and which allow Member States, in addition to the possibilities that the Treaty exceptions already offer, to deviate from the four freedoms under certain conditions (see above). This gives Member States ample possibilities to protect public interests and national values. Regulatory diversity can thus be upheld either under the Treaty exceptions or under the case law-based exceptions.

The consequence of this development towards more coherence in the Court's case law is that it is increasingly irrelevant how an activity or situation should be classified, under goods, services, persons or capital, since their legal consequences are (almost) identical. Differences relating to the specific nature of the economic factors involved can be taken into account under the exceptions and particularly the 'rule of reason' case law of the Court.

There are also other arguments which support a high degree of coherence 
between the four freedoms. As the European Commission in its White Paper on the Future of Europe (2017, p. 10) observes, the digitization of society blurs the lines between workers and the self-employed, goods and services, or consumers and producers. Dividing lines between the four factors of production become increasingly blurred. At the same time, though, there have been pleas by academics, several organizations, Member States and the European Commission to add a fifth freedom to the internal market: the freedom of movement of data, which is particularly relevant for the UK's relatively strong digital economy. ${ }^{20}$ The importance of free movement of data within the context of the (digital) Single Market can hardly be underestimated.

\section{Differentiation and Fragmentation}

In contrast with the foregoing, though, there are signs indicating that the internal market is more diverse and heterogeneous. According to Weatherill, in his paper on several internal markets, 'the character of the internal market is neither unambiguous nor homogeneous - legally, economically or politically' (Weatherill 2017, p.2). He refers to a number of developments in EU law that reveal a 'kaleidoscope' of different patterns, sector by sector, and an increasingly less homogeneous internal market (Weatherill 2017, pp. 2, 8). Nic Shuibhne identifies four key drivers of fragmentation in EU free movement case law: proliferation of the tests and concepts underpinning the four freedoms; the multiple and unsettled objectives of the internal market; the realization of the protection of fundamental rights; and the structure of the Court (Shuibhne 2013, pp. 41-62).

Technological developments and digitalization pose new challenges to the (digital) internal market. On the one hand, as the lines between goods, services and persons are blurring, these developments may reinforce the unity of the internal market. On the other hand, there may be less emphasis on mobility and free movement as neither consumers nor businesses will have to use wide-reaching mobility rights to engage in cross-border trade, which may well fit in a 'commuting model' ${ }^{21}$ And the digital internal market raises important concerns about citizens' rights to protection of personal data, the right to protection of intellectual property, and the freedom of speech and information. ${ }^{22}$ The following examples reveal a more ambiguous and fragmented internal market than we might expect.

Firstly, whereas it has been accepted in the case law of the CJEU that the free movement of persons and services may apply under certain conditions in horizontal situations, which means that the freedoms can be invoked by 
citizens vis-à-vis other citizens and private parties, this is different for the free movement of goods, which provision has not explicitly been granted horizontal direct effect. ${ }^{23}$

Secondly, looking at the substantive scope of application, the Court in the above-mentioned Keck case has placed certain types of national measures beyond the scope of application of the free movement of goods provision. ${ }^{24}$ This limits the reach of the free movement of goods provision to national regulatory choices in matters that are truly local. But the CJEU, ever since Keck, has not only struggled to uphold its often criticized and rather formalistic line of reasoning, but it has also not delivered a similar judgment in respect of the other freedoms (Weatherill 2017, 1996; De Vries 2009, p. 125).

Looking more specifically at the free movement of workers, even though the Court endorsed a market access approach in the Bosman case, ${ }^{25}$ the focus seems to be laid more on the principle of non-discrimination. Furthermore, in practice and particularly since the extension of the EU eastwards, due to the differences between the labour markets, access to these markets also differs considerably across the EU. As bEUcitizen research has shown, due to all kinds of legal but mostly practical, bureaucratic and linguistic barriers, the free movement of workers or professionals within the internal market is particularly problematic (Pennings and Seeleib Kaiser 2017).

Thirdly, with regard to the exceptions to the four freedoms, the CJEU adopts a differentiated approach in the sense that Member States enjoy different degrees of discretion under the justification grounds. Certain values are considered more important than others, such as public health, ${ }^{26}$ or in certain policy fields Member States are primarily competent to regulate these matters (De Vries 2006). As stated above, though, when it comes to social rights and the protection of workers' interests, the Court has, at least so far, been less forbearing. ${ }^{27}$

Fourthly, the EU Charter may be a source of proliferation and fragmentation. The Charter mandates the integration of public values and fundamental rights into EU internal market law (Weatherill 2017, p. 16) and may constitute an important counterweight to the four economic freedoms (De Vries 2015, p. 242). But the economic rights of the EU Charter such as the freedom to conduct a business or the right to property, which according to the CJEU constitute a specific amplification of fundamental economic rights, may also reinforce or broaden the scope of the four economic freedoms.

The EU Charter plays an important role in the interpretation of EU legislation, which may lead to an overstretching of economic freedoms and rights. This happened in the above-mentioned Alemo Herron case, 
where the Court focused on the freedom to conduct a business in interpreting the transfer of undertakings Directive and thereby sidelined the right to workers' protection, which was a specific aim of the Directive and could serve as a counterweight. This brings me to another problem, which relates to the limited scope of application of the EU Charter and the Court's limited jurisdiction. National measures can only be assessed under the EU Charter if they fall within its scope of application..$^{28}$ Due to the broad legislative powers of the EU in the field of the internal market, fundamental rights that have a close nexus to the internal market, such as the right to data protection, the right to (intellectual) property, the freedom to conduct a business, or media pluriformity, could be embraced much more easily by the EU legislator than other fundamental rights. In addition, in a preliminary ruling procedure before the CJEU certain fundamental rights, which are not covered by the relevant EU legislation, remain out of sight. An example is the Court's judgment in Google Spain, where in interpreting the data protection Directive hardly any attention is given to the freedom of speech or freedom of information, or the economic rights of Google. The central question relates to Mr Costeja González's request to order Google Spain SL and Google Inc to withdraw personal data relating to $\mathrm{Mr}$ Costeja González from its index and to prevent access to the data in the future. In particular, he wanted the links to two pages of the La Vanguardia newspaper to be removed, in which an announcement mentioning his name appeared for a real-estate auction connected with attachment proceedings for the recovery of social security debts. The Court even held that the rights to privacy and protection of personal data as enshrined in Articles 7 and 8 of the EU Charter 'override, as a rule, not only the economic interest of the operator of the search engine but also the interest of the general public in finding that information upon a search relating to the data subject's name'. ${ }^{29}$ The problem is thus (almost) exclusively viewed through the lens of the data protection Directive. In other words, the EU Single Market framework allows the ECJ to provide for a far-reaching right to protect personal data, which in principle deserves approval, although possibly at the cost of other fundamental rights such as the freedom of expression or the freedom to receive information (De Vries 2015).

Fifthly, the human rights dimension in the field of the free movement of persons and citizenship is more visible than in the fields of goods and services (Prechal and De Vries 2009, p.16). 'Natural persons are not mere economic units and must be treated with dignity' (Oliver 2011, p. 1426), which may entail a different judicial and legislative approach. In order to assess whether the substance of EU citizens' rights has been undermined, fundamental rights, such as the right to family life and the 
rights of the child, inevitably need to be taken onboard. This may explain why in the field of citizenship, the Court has developed its own strand of case law including a 'new' test, which has in some cases been applied in internal situations where normally EU law and the four freedoms do not apply (Van Eijken and De Vries 2011). Finally, with respect to the EU's legislative activity, a rather blurred and heterogeneous picture arises, since due to various levels of legislative intensity or different harmonization techniques, for example minimum harmonization vis-à-vis total harmonization, the integration of the markets in goods, services or persons varies considerably (Weatherill 2017).

\section{Coherence is Essential}

Despite the above-mentioned ambiguity and (lurking) fragmentation in EU internal market law, coherence is essential as the four economic freedoms form part of a coherent whole and serve the same end: the creation of the Single Market (Oliver 2011, p. 1426). Coherence is also important as it leads to more legal certainty and uniformity in the field of free movement. A coherent case law practice contributes to the rule of law and the avoidance of arbitrary decision-making, and is considered as belonging to institutional responsibility of the Court of Justice (Shuibhne 2013).

Furthermore, politically the four freedoms are considered indivisible. According to Weatherill:

the EU is and always has been about more than market-making. In October 2016 Martin Schulz, at the time the President of the European Parliament, captured the mood: 'I refuse to imagine a Europe where lorries and hedge funds are free to cross borders but citizens are not'. This does not mean identical treatment sector-by-sector, but it does entail a political commitment not to accept priorities or hierarchies that entrench divisions between the freedoms. (Weatherill 2017, p. 43)

Divergences are allowed as there are 'differences between the freedoms, which are inherent in life and in the Treaty' (Oliver 2011, p. 1426); however, they should be unnecessary, and undermine the unity of the internal market. This unity has been essential for the development and protection of fundamental economic rights of citizens, for the right of citizens to develop themselves economically and socially within the single area of the internal market (Barents 2013). 


\section{CONCLUSION}

The two major challenges for economic rights of citizens - that is, the creation of an inclusive internal market, and the prevention of fragmentation and division between the four freedoms - are ultimately related. After all, according to Nic Shuibhne, one of the key drivers for fragmentation relates to the unsettled objectives of the internal market: 'what kind of internal market is the Union trying to establish?' (Shuibhne 2013, p. 43). The Treaty of Lisbon and the binding EU Charter make it clear that the EU Single Market should not be pictured as a narrowly defined trade project, as it embraces public and social values, and fundamental rights. And this means that it is hard to envisage an internal market without persons and citizens.

There are various possibilities within the current Treaty framework to strengthen the social face of the EU. The revision of the posting of workers Directive together with the policy initiatives of the EU, including the European Pillar for Social Rights, show that there is a growing political willingness to implement the idea of the social market economy. This is crucial for the viability of EU citizens' economic rights. But more is needed. At the outer end of the spectrum lies the outdated institutional structure of the EU with limited competences in the social policy field, which may have to be redesigned. Meanwhile, though, the EU institutions and particularly the CJEU should preserve coherence in the application of EU law and the unity of the internal market, which after all brings together the legal, economic and political order within the EU and recognizes the EU's vocation beyond trade liberalization (Weatherill 2017).

\section{NOTES}

1. Schraad-Tischler and Schiller (2016).

2. Barnard (2016, p. 20).

3. Case C-26/62, Judgment of the Court of 5 February 1963. Van Gend \& Loos $v$ Nederlandse Administratie der Belastingen; Case C-6/64, Judgment of the Court of 15 July 1964. Costa v. Enel.

4. Case C-390/12, Judgment of the Court of 30 April 2014. Pfleger and Others.

5. Joined cases C-267/91 and C- 268/91, Judgment of the Court of 24 November 1993. Keck and Mithouard.

6. Oliver and Wulf-Henning (2004, p. 410).

7. Opinion of AG Trstenjak in Case C-271/08, Commission v. Germany, paras. 183 a.f.

8. Case C-120/78, Judgment of the Court of 20 February 1979. Rewe-ZentralAG $v$ Bundesmonopolverwaltung für Branntwein.- Cassis de Dijon; case C-275/92, Judgment of the Court of 24 March 1994. Her Majesty's Customs and Excise v. Gerhart Schindler; case C-2/90, Judgment of the Court of 9 July 1992. Commission v. Belgium -Waalse Afvalstoffen; case C-137/09, Judgment of the Court of 16 December 2010. Josemans 
v. Burgemeester van Maastricht; case C-244/06, Judgment of the Court of 14 February 2008. Dynamic Medien v. Avides Media AG; case C-379/87, Judgment of the Court of 28 November 1989. Groener v. Minister for Education.

9. Case C-112/00, Judgment of the Court of 12 June 2003. Schmidberger v. Republic of Austria.

10. Case C-36/02, Judgment of the Court of 14 October 2004. Omega Spielhallen v. Oberbürgermeisterin der Bundesstadt Bonn.

11. Case C-438/05, Judgment of the Court (Grand Chamber) of 11 December 2007. International Transport Workers Federation v. Viking; case C-341/05, Judgment of the Court (Grand Chamber) of 18 December 2007. Laval un Partneri Ltd v. Svenska Byggnadsarbetareförbunde.

12. Case C-293/12, Judgment of the Court (Grand Chamber) of 8 April 2014. Digital Rights Ireland v. Minister for Communications; case C-362/14, Judgment of the Court (Grand Chamber) of 6 October 2015. Schrems v. Data Protection Commissioner.

13. Case C-149/77, Judgment of the Court of 15 June 1978. Defrenne v. Société Anonyme Belge de Navigation Aérienne Sabena.

14. Council Directive 2001/23/EC of 12 March 2001 on the approximation of the laws of the Member States relating to the safeguarding of employees' rights in the event of transfers of undertakings, businesses or parts of undertakings or businesses, OJ 2001, L82/16; Directive 2008/94/EC of the European Parliament and of the Council of 22 October 2008 on the protection of employees in the event of the insolvency of their employer (Codified version), OJ 2008, L283/36.

15. Committee on Employment and Social Affairs (2016).

16. Case C-176/12, Judgment of the Court of 15 January 2014. Association de Mediation Sociale v. Union locale des syndicats CGT.

17. Case C-426/11, Judgment of the Court of 18 July 2013. Alemo Herron v. Parkwood Leisure Ltd.

18. Council of the EU, Press release of 24 October 2017, Posting of workers: Council reaches agreement, http://www.consilium.europa.eu/en/press/press-releases/2017/10/24/ posting-of-workers-council-reaches-agreement/ (accessed 26 October 2017).

19. Case C-171/11, Judgment of the Court of 12 July 2012. Fra.bo SpA v. Deutsche Vereinigung des Gas.

20. Bhaskar Chakravorti (2017), There's a fifth freedom Brexit negotiators need to keep in mind, World Economic Forum, https://www.weforum.org/agenda/2017/08/theres-afifth-freedom-brexit-negotiators-need-to-keep-in-mind; EU2017.EE (2017), Estonian Vision Paper on the Free Movement of Data - the Fifth Freedom of the European Union, https://www.eu2017.ee/news/insights/FreeMovementOfData; National Board of Trade Sweden (2016), Data flows - a fifth freedom for the internal market?, https://www. kommers.se/Documents/dokumentarkiv/publikationer/2016/Data $\% 20$ flows $\% 20-\% 20$ A $\% 20$ fifth $\% 20$ freedom $\% 20$ for $\% 20$ the $\% 20$ internal $\% 20$ market.pdf.

21. See bEUcitizen policy brief, 'Reinforcing Economic Rights of EU citizens', http://beucitizen.eu/wp-content/uploads/2017-03-21-POLICY-BRIEF-WP5-De-Vries-Ioriatti. pdf (accessed 9 November 2017).

22. Brussels, 19.4.2016 COM(2016) 179 Final Communication From The Commission To The European Parliament, The Council, The European Economic And Social Committee And The Committee Of The Regions EU eGovernment Action Plan 2016-2020 Accelerating the digital transformation of government.

23. Case C-171/11, Judgment of the Court of 12 July 2012. Fra.bo SpA v. Deutsche Vereinigung des Gas.

24. Joined cases C-267/91 and C- 268/91, Judgment of the Court of 24 November 1993. Keck and Mithouard.

25. Case C-415/93, Judgment of the Court of 15 December 1995. Union royale belge des sociétés de football association ASBL v. Bosman.

26. Case C-15/74, Judgment of the Court of 31 October 1974. De Peijper v. Sterling Drug Inc. 
27. Case C-438/05, Judgment of the Court (Grand Chamber) of 11 December 2007. International Transport Workers Federation v. Viking.

28. Case C-617/10, Judgment of the Court of 7 May 2013. Aklagaren v. Akerberg Fransson; case C-390/12, Judgment of the Court of 30 April 2014. Pfleger and Others.

29. Case C-131/12, Judgment of the Court (Grand Chamber), 13 May 2014. Google Spain SL e Google Inc. v. Agencia Española de Protección de Datos, para. 97.

\section{REFERENCES}

Barents, R. (2013), De constitutionele paradox van het Unierecht. SEW Tijdschrift voor Europees en Economisch Recht, 7, p. 302.

Barnard, Catherine (2015), The silence of the Charter: social rights and the Court of Justice. In: Sybe de Vries, Stephen Weatherill and Ulf Bernitz (2015), The EU Charter of Fundamental Rights as Binding Instrument: Five Years Old and Growing, Oxford: Hart Publishing, pp. 173-188.

Barnard, Catherine (2016), The Substantive Law of the EU - the Four Freedoms, Oxford: Oxford University Press.

Barnard, Catherine and Steve Peers (2017), European Union Law, Oxford: Oxford University Press.

Chalmers, Damien (1995), The single market; from prima donna to journeyman. In: J. Shaw and G. More (eds), New Legal Dynamics of European Union, Oxford: Clarendon Press, pp. 55-72.

Committee on Employment and Social Affairs (2016), Draft report on the proposal for a directive of the European Parliament and of the Council amending Directive 96/71/EC of The European Parliament and of the Council of 16 December 1996 concerning the posting of workers in the framework of the provision of services. http://www.europarl.europa.eu/sides/getDoc.do?pubRef=- $\% 2 \mathrm{f} \% 2 \mathrm{fEP} \% 2 \mathrm{f} \% 2 \mathrm{fN}$ ONSGML $\% 2$ bCOMPARL $\% 2 b P E-582.163 \% 2 b 01 \% 2 b D O C \% 2 b P D F \% 2 b V 0 \% 2$ $\mathrm{f} \% 2 \mathrm{fEN}$.

De Schutter, Olivier (2006), The balance between economic and social objectives in the European Treaties. Revue française des affaires sociales, 2006 (5), pp. 119-143.

De Vries, Sybe (2006), Tensions within the Internal Market: The Functioning of the Internal Market and the Development of Horizontal And Flanking Policies, Groningen: Europa Law Publishing.

De Vries, Sybe (2009), 'Goods revisited' - Nieuwe inzichten in de rechtspraak over het vrij verkeer van goederen. Nederlands Tijdschrift voor Europees recht, 4, pp. 121-130.

De Vries, Sybe (2015), The EU Single Market as 'normative corridor' for the protection of fundamental rights: the example of data protection. In: Sybe de Vries, Ulf Bernitz and Stephen Weatherill (eds), The EU Charter of Fundamental Rights as a Binding Instrument: Five Years Old and Growing, Oxford: Hart Publishing, pp. 235-260.

De Vries, Sybe, Elena Ioriatti, Paolo Guarda and Flavio Guella (2015), Research paper on the categorization of economic rights. Deliverable 5.1 of the bEUcitizen project. DOI: 10.5281 /zenodo.46830.

European Commission(2017), White Paper on the Future of Europe, COM(2017)2025, 1 March 2017. 
Marshall, T.H. (1950), Citizenship and Social Class and Other Essays, Cambridge: Cambridge University Press.

Mortelmans, Kamiel (1985), Ordenend en sturend beleid en economisch publiekrecht, Deventer: Kluwer.

Mortelmans, Kamiel (1991), Article 30 of the EEC Treaty and legislation relating to market circumstances: time to consider a new definition? Common Market Law Review, 28 (1), pp. 115-136.

Nic Shuibhne, Niamh (2013), The Coherence of EU Free Movement Law: Constitutional Responsibility and the Court of Justice, Oxford Studies in European Law, Oxford: Oxford University Press.

O'Leary, Siofra (2011), Free movement of persons and services. In: P. Craig and G. de Búrca (eds), The Evolution of EU Law, Oxford: Oxford University Press, pp. 499-546.

Oliver, Peter (2004), Free Movement of Goods in the European Union, Oxford: Hart Publishing.

Oliver, Peter (2011), Of trailers and jet skis: is the case law on Article 34 TFEU hurtling in a new direction? Fordham International Law Journal, 33, 1423-1471.

Oliver, Peter and Roth Wulf-Henning (2004), The Internal Market and the Four Freedoms. Common Market Law Review, 41, pp. 407-441.

Pennings, Frans and Martin Seeleib-Kaiser (2017), Entitlements and Impediments to Access Social Rights by EU Citizens, Cheltenham, UK and Northampton, MA, USA: Edward Elgar Publishing.

Polyani, Karl (1994), The Great Transformation: The Political and Economic Origins of Our Time, New York: Rinehart.

Prechal, Sacha (2006), Juridisch Cement voor de Europese Unie, Groningen: Europa Law Publishing.

Prechal, Sacha and Sybe de Vries (2009), Seamless web of judicial protection in the internal market. European Law Review, 34 (1), pp. 5-25.

Schraad-Tischler, Daniel and Christof Schiller (2016), Social Justice in the EU - Index Report 2016; Social Inclusion Monitor Europe. https://www.bertels mannstiftung.de/fileadmin/files/BSt/Publikationen/GrauePublikationen/Studie NW_Social-Justice-Index_2016.pdf.

Snell, Jukka (2010), The notion of market access: a concept or a slogan? Common Market Law Review, 47 (2), pp. 437-472.

Van Eijken, Hanneke and Sybe de Vries (2011), A new route into the promised land? Being a European citizen after Ruiz Zambrano. European Law Review, 36, pp. 704-721.

Veldman, Albertine and Sybe de Vries (2015), Regulation and enforcement of economic freedoms and social rights - a thorny distribution of sovereignty. In: Ton van den Brink, Michiel Luchtman and Miroslava Scholten (eds), Sovereignty in the Shared Legal Order of the EU: Core Values of Regulation and Enforcement, Cambridge: Intersentia, pp. 65-92.

Verschueren, Herwig (2015), The European internal market and the competition between workers. European Labour Law Journal, 6 (2), pp. 128-151.

Weatherill, Stephen (1996), After Keck: some thoughts on how to clarify the clarification. Common Market Law Review, 33 (5), pp. 887-908.

Weatherill, Stephen (2013), From economic rights to fundamental rights. In: Sybe de Vries, U. Bernitz and S. Weatherill, The Protection of Fundamental Rights in the EU after Lisbon, Oxford: Hart Publishing, pp. 11-37.

Weatherill, Stephen (2015), Protecting the internal market from the charter. 
In: Sybe de Vries, Ulf Bernitz and Stephen Weatherill (eds), The EU Charter of Fundamental Rights as a Binding Instrument, Oxford: Hart Publishing, pp. 213-234.

Weatherill, Stephen (2017), The several internal markets. Yearbook of European Law, https://ssrn.com/abstract $=3032513$. 